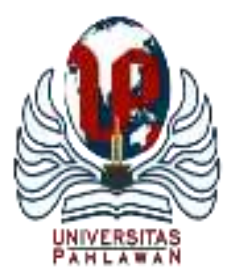

\title{
JURNALBASICEDU
}

Volume 6 Nomor 1 Tahun 2022 Halaman 524 - 530

Research \& Learningin Elementary Education https://jbasic.org/index.php/basicedu

\section{Efektivitas Media Pembelajaran Edmodo Terhadap Kemampuan Berpikir Kritis pada Pembelajaran Tematik Siswa Sekolah Dasar}

\author{
Vivi Rulviana \\ Universitas PGRI Madiun, Indonesia \\ E-mail: rulvianavivi@gmail.com
}

\begin{abstract}
Abstrak
Kurangnya pemanfaatan media pembelajaran yang menarik menyebabkan lemahnya kemampuan yang dimiliki siswa salaha satunya dalam berpikir kritis, dimana terlihat banyak siswa yang kurang mampu berargumen secara mandiri dan masih sering menirukan jawaban dari teman yang dianggap benar. Tujuan dari penelitian ini yaitu untuk menganalisis efektivitas media pembelajara edmodo terhadap kemampuan berpikir kritis pada pembelajaran tematik siswa kelas VI SD. Jenis penelitian ini yaitu kuantitatif. Jenis Metode yang digunakan Quasi Eksperiment dengan desain nonequivalent design control grup. Teknik yang digunakan untuk mengumpulkan data yaitu tes. Postes diberikan kepada siswa di kelas kontrol dan eksperimen.Teknik yang digunakan untuk menganalisis yaitu analisis deskriptif. Dengan demikian dapat disimpulkan bahwa media edmodo lebih efektif terhadap kemmapuan berpikir kritis pada pembelajaraan tematik.
\end{abstract}

Kata Kunci: media, Edmodo, kemampuan berpikir kritisl.

\begin{abstract}
The lack of use of interesting learning media causes the weak ability of students, one of which is in critical thinking, where it can be seen that many students are not able to argue independently and still often imitate answers from friends who are considered correct. The purpose of this study is to analyze the effectiveness of the Edmodo learning media on critical thinking skills in thematic learning of sixth grade elementary school students. This type of research is quantitative. The type of method used is Quasi Experiment with a nonequivalent design control group. The technique used to collect data is a test. Posttest was given to students in the control and experimental classes. The technique used to analyze was descriptive analysis. Thus, it can be concluded that Edmodo media is more effective towards critical thinking skills in thematic learning.
\end{abstract}

Keyword: Media, Edmodo, Critical Thinking Ability

$\checkmark$ Corresponding author :

Email: :rulvianavivi@gmail.com

DOI $\quad:$ https://doi.org/10.31004/basicedu.v6i1.1867 


\section{PENDAHULUAN}

Pembelajaran tematik adalah komponen dari kurikulum 2013 dan sudah diterapkan di sekolah dasar. Menurut (Muklis, 2012) pembelajaran tematik mampu menciptakan keaktifan siswa. Pembelajaran tematik memberikan kebebasan pada anak untuk dapat mempelajarai materi (Sedono, 2012). Implementasi pembelajaran tematik sebagai bentuk pembelajaran yang mengarah pda keteramplan 4C (Communication, Collaboration, Crital Thinking, dan Creativity). Pembelajran tematik membutuhkan langkah dalam pemecahan masalh dengan menggunakan keteramplan. Salahsatu keterampilan yang harus dimiliki dan dikembangkan yaitu keterampilan berpikir kritis. Keterampilan berpikir kritis tidak bisa didapatkan secara instan namun harus melalui tahap latihan dan pembiasaan (Mauliana Wayudi, 2020).

Kemampuan berpikir kritis dimulai dengan individu mampu mengkritisi dan menilai situasi kondisi dan fenomena yang ada. Berpikir kritis yaitu kemampuan pengambilan keputusan secara rasional (Kustandi, 2017; Winoto, 2020; Diyanah, 2020). Pentingnya berpikir kritis bagi siswa untuk memecahkan segala permasalahan. Namun faktanya di SDN 04 Madiun Lor, terdapat permasalahan peserta didik masih lemah dalam berpikir kritis, ada beberapa peserta didik kurang aktif dalam berargumen, mengikuti jawaban yang dilontarkan oleh teman, dan belum mengembangkan ide sendiri.

Salah satu penyebab munculnya permasalahan tersebut yaitu proses pembelajaran yang dilaksanakan oleh guru kurang efektif. Guru belum memanfaatkan media yang sesuai dengan kebutuhan, perkembangan ilmu pengetahuan dan teknologi. Padahal mengikuti perkembangan teknologi yang ada, berpikir kritis dalam berbagai kegiatan dapat berkembang dengan pelaksanaan pembelajaran yang memanfaatkan medi pembelajaran yang tepat. Media pembelajaran berbasis internet semakin banyak digunakan untuk menunjang kegiatan pembelajaran (Azhar, 2019). Menurut (Siti Aisyah, 2021) dengan penggunaan media pembelajaran maka belajar akan lebih efektif dan efisien. Macam media berbasis internet diantaranya edmodo, moodle. quipper school, web, kippin school,dll ( (Sari, 2021). Salah satu media yang mampu menunjang kegiatan pembelajaran berbasis internet dan gratis yaitu edmodo. Edmodo menyerupai facebook dalam pembelajaran di sekolah (Gatot, 2013; Purnawarman, 2016). Edmodo merupakan suatu platform yang menyediakan berbagai fitur berbasis e-learning (Gede Suriadhi, 2015; Nur, 2021; Hobsbawm, 2014). Melalui edmodo guru dapat memberikan soal-soal berbasis online dan bahan ajar untuk melatih kemampuan peserta didik, dapat membantu pengajar membangun sebuah kelas virtual, serta mengurangi dampak negatif dari penggunaan internet oleh siswa sekolah (Shams-abadi,2015; Inel, 2013). Hal tersebut juga didukung oleh penelitian terdahulu yang menggunakan media edmodo di dalam kelas seperti (Masnur, 2021; Hertiawi, 2020). Hasil penelitian tersebut menunjukkan penggunaan media edmodo lebih efektif dan layak digunakan dalam proses pembelajaran sehingga dapat meningkatkan kemampuan berpikir kritis siswa. Berdasarkan permasalahan tersebut maka tujuan dari penelitian berikut untuk menganalisis efektivitas media pembelajaran edmodo terhadap kemampuan berpikir kritis pada pembelajaran tematik siswa kelas VI SD.

Hasil penelitian ini bermanfaat secara praktis. Secara teoritis dapat menambah wawasan keilmuan khususnya dalam hal pemanfaatan media edmodo terhadap kemampuan berpikir ktitis siswa. Secara praktis bermanfaat bagi siswa untuk meningkatkan kemampuan berpikir kritis, dan pada guru bermanfaat meningkatkan keprofesionalan guru dalam pembelajaran khususnya untuk meningkatkan kemampuan berpikir kritis siswa.

\section{METODE PENELITIAN}

Jenis penelitian ini adalah penelitian kuantitatif. Penelitian ini merupakann penelitian kuantitatif dengan mengunakan metode eksperimen. Model yang digunakan yaitu Quasi Eksperimen. Desain 
tersebut memiliki kelas kontrol namun tidak sepenuhnya variabel luar yang mempengaruhi pelaksanaan eksperimen (Sugiyono, 2017).

Dalam penelitian berikut populasi yang digunakan seluruh siswa kelas VI yang ada di SDN 04 Madiun Lor. Sampel yang diambil di penelitian ini yaitu siswa kelas VIA berjumlah 32 siswa sebagai kelas kontrol dan kelas VIB berjumlah 32 sebagai kelas eksperimen. Rancangan eksperimen yang digunakan dalam penelitian ini Nonequivalent Control Group Design. Dalam rancangan ini terdapat pretest dan postest. Sebelum diberi perlakuan kelompok kontrol dan eksperimen diberikan pretest terlebih dahulu untuk mengukur kondisi awal siswa. Pada kelompok kontrol tidak diberikan perlakuan yang sama yaitu dengan tidak menggunakan media. Sedangkan pada kelas eksperimen diberikan perlakuan dengan menggunakan media edmodo dalam pembelajatran.

Teknis analiisis datanya menggunakan statisktik deskriptif. Analisis yang digunakan dengan menggunakan uji-t.

$$
t_{\text {hitung }}=\frac{\bar{X}-\bar{Y}}{\sqrt{\frac{s_{1}^{2}}{n_{1}}+\frac{S_{2}^{2}}{n_{2}}-2 r\left(\frac{s_{1}}{\sqrt{n_{1}}}\right)\left(\frac{S_{2}}{\sqrt{n_{2}}}\right)}}
$$

(Siregar, 2013:386)

Krteria pengujian adalah harga th itung $<0,05$, maka H0 diterima dan Ha ditolak, dan jika $t h$ itung $>$ t tabel maka $\mathrm{H} 0$ ditolak dan Ha diterima dan kelompok dinyatakan tidak setara.

\section{HASIL DAN PEMBAHASAN}

Penelitian ini dilakukan untuk menguji keefektifan media pembelajaran edmodo terhadap kemampuan berpikir kritis siswa pada pembelajaran tematik. Penelitian berikut memilikii variabel bebas yaitu Media Pembelajaran Edmodo (X) dan variabel terikat yaitu kemampuan berpikir kritis pada pembelajaran tematik (Y). Penelitian ini dilakukan pada kelas kontrol dan kelas eksperimen. Kelas kontrol dilakukan pada kelas VA dan kelas eksperimen pada kelas VB di SDN 04 Madiun Lor. Penelitian di kelas dilakukan dengan 2 kali pertemuan. Peneliti menggunakan pretest dan posttest sebagai salah satu instrumen untuk mengetahui hasil analisis deksriptif dari kemampuan berpikir kritis siswa pada pembelajaran tematik kelas V.

Pada kelas kontrol, pertemuan pertama siswa mendapatkan soal pretest. Selanjutnya pada pertemuan kedua siswa mendapatkan materi pembelajaran dengan metode konvensional tanpa menggunakan media pembelajaran yang mendukung dan mendapatkan soal posttest. Sedangkan pada kelas eksperimen, pertemuan pertama siswa mendapatkan soal pretest. Selanjutnya pertemuan kedua siswa mendapatkan materi pembelajaran dengan menggunakan media pembelajaran edmodo dan mendapatkan soal posttest.

Data pretest pada kelas kontrol didapat dari tes kemampuan berpikir kritis yang dilakukan setelah siswa diberi pembelajaran tanpa menggunakan media. Subjek yang diberikan tes berjumlah 32 siswa. Data hasil pretest kelas kontrol dapat dilihat pada grafik berikut :

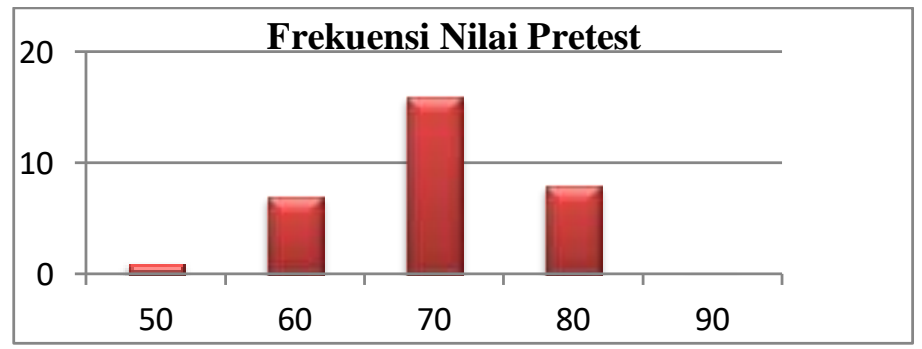

Gambar 1.Grafik Nilai Pretest 
Dari grafik di atas, satu siswa memperoleh nilai 50,00, tujuh siswa mendapat nilai 60,00, enam belas siswa mendapat nilai 70,00, delapan siswa mendapat nilai 80 dan tidak ada siswa yang mendapat nilai 90,00.

Sedangkan data posttest pada kelas kontrol didapat dari tes yang dilakukan setelah siswa diberi pembelajaran secara konvensional. Subjek yang diberikan tes berjumlah 32 siswa. Data hasil posttest kelas kontrol dapat dilihat pada garfik berikut:

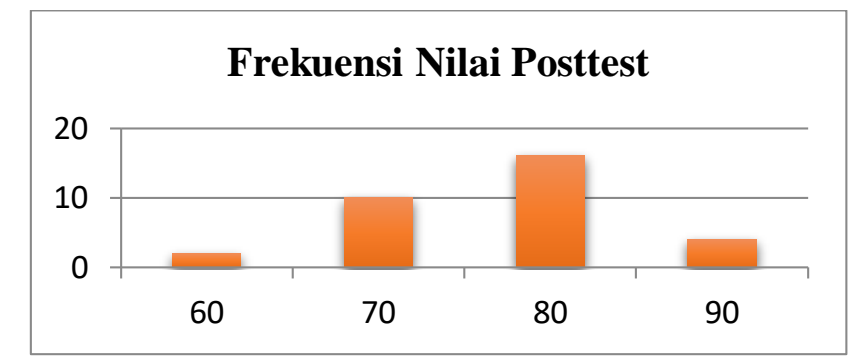

Gambar2. Grafik Nilai Posttest

Data pretest kemampuan berpikir kritis yang dilakukan sebelum siswa menerima materi. Subjek yang diberikan tes berjumlah 32 siswa. Hasil rata-rata pretest sebesar 75,3125 dengan varian 90,22 dan standar deviasi/simpangan baku 9,49. Nilai maksimum didapat 90 dan minimalnya 50, maka selisihnya sebesar 40 . Median didapat 80 sedangkan modus didapat 80.

Berikut ini grafik nilai pretest:

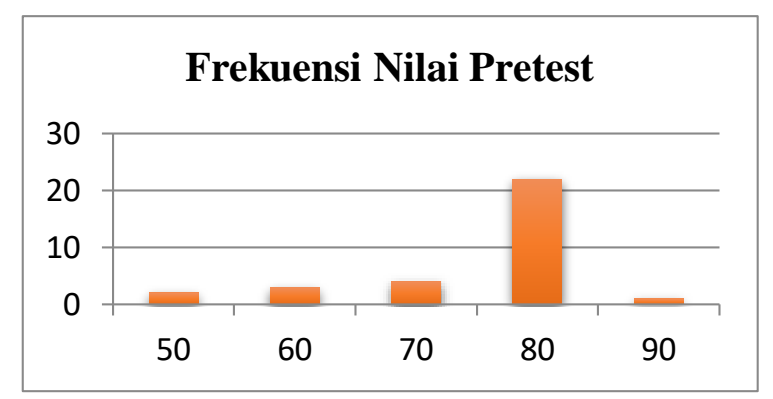

Gambar 3 Grafik Nilai Pretest

Peneliti melakukan posttest, setelah siswa diberi pembelajaran menggunakan media edmodo. Subjek penelitian sejumlah 32 siswa. Berdasarkan penelitian diperoleh hasil rata-rata posttest sebesar 89,68 dengan varian 106,35 dan standar deviasi/simpangan baku 10,310. Nilai maksimum didapat 100 dan minimalnya 70, maka selisihnya sebesar 30 median didapat 90 sedangkan modus didapat 80. Berikut grafik nilai postest:

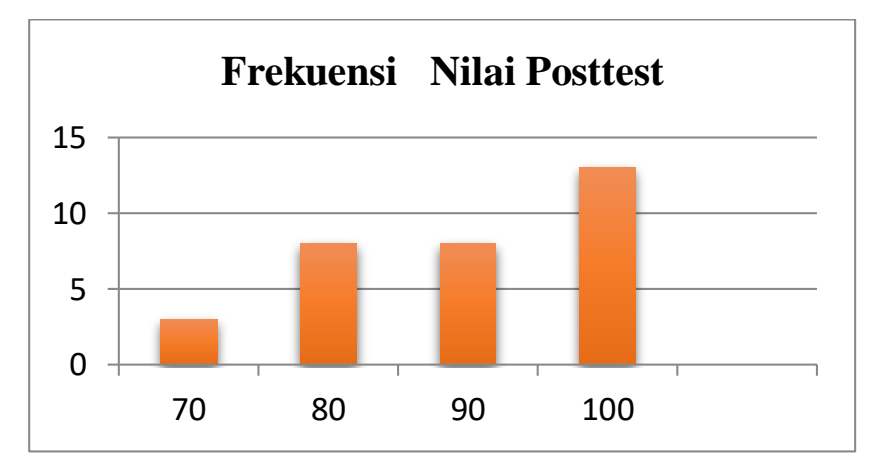

Gambar 4 Grafik Nilai Posttest 
Selanjutnya dilakukan uji normalitas yang mendapatkan hasil signifikansi atau L hitung data pretest yaitu 0,845233 . Hasil tersebut menunjukkan bahwa L hitung $(0,845233) \geq \mathrm{L}$ tabel $(0,15662565)$, maka hasil pretest bedistribusi normal. Berikutnya uji normalitas data postest menunjukkan hasil signifikansi atau L hitung data posttest yaitu 0,97187 . Hasil tersebut menunjukkan bahwa L hitung $(0,97187) \geq$ tabel $(0,15663)$. Jadi dapat disimpulkan jika hasil posttest berdistribusi normal.

Setelah uji normalitas dilanjutkan uji homogenitas. Hasil uji homogenitas pretest postest ditunjukkan dalam tabel berikut.

Tabel 1 Hasil Uji Homogenitas Pretest dan Posttest

\begin{tabular}{lll}
\hline \multicolumn{3}{l}{ F-Test Two-Sample for Variances } \\
\hline Mean & Variable 1 & Variable 2 \\
\hline Variance & 75,3125 & 89,6875 \\
\hline Observations & 90,22177 & 106,3508065 \\
\hline Df & 32 & 32 \\
\hline F & 31 & 31 \\
\hline P(F<=f) one-tail & 0,548341 & \\
\hline F Critical one-tail & 0,324936 & \\
\hline
\end{tabular}

Data di atas $\mathrm{F}_{\text {hitung }}(0,5483) \leq \mathrm{F}_{\text {tabel }}(0,54880)$ dan $\mathrm{H}_{0}$ diterima (homogen).

Setelah dilakukan uji normalitas dan homogenitas, maka selanjtnya dilakukan uji hipotesis. Hasil uji pembelajaran menggunakan media pembelajaran edmodo lebih tinggi dibanding pembelajaran tanpa media atau metode konvensional. Berdasarkan perhitungan nilai t hitung $(-6,27078) \leq \mathrm{t}$ tabel $(2,0395)$, sehingga $\mathrm{H}_{0}$ diterima, $\mathrm{H}_{1}$ di tolak. Hal tersebut tidak ada hasil yang signifikan terhadap kemampuan berpikir kritis pada pembelajaran tematik siswa kelas VIA. Berdasarkan data di atas nilai $t$ hitung $(9,265) \geq \mathrm{t}$ tabel $(2,0395)$, sehingga $\mathrm{H}_{\mathrm{o}}$ ditolak, $\mathrm{H}_{1}$ diterima, maka ada hasil yang signifikan terhadap kemampuan berpikir kritis pada pembelajaran tematik siswa kelas VIB.

Pada saat pembelajaran dimulai dengan menggunakan media edmodo siswa menjadi lebih aktif dan dapat memahami pembelajaran. Dalam fitur edmodo terdapat library dimana fitur ini sebagai tempat untuk menyimpan materi pembelajaran, selain itu ada quiz dimana dalam mengerjakan tugas di batasi oleh waktu, sehingga siswa lebih giat untuk membuka media edmodo untuk segera mengerjakan. Karena didalam media edmodo banyak fitur selain informasi dan pembelajaran dari guru, mereka juga dapat mengakses link atau tautan yang di kirimkan oleh guru. Disini siswa memilki keingintahuan yang tinggi sehingga mengakses yang di perintahkan oleh guru mereka. Siswa tidak merasa bosan karena pembelajaran berbasis internet terlihat ketika guru memberikan tugas mereka segera mengerjakan dan memberikan argumen, ide dalam kolom komentar. Dimanapun mereka dapat mengakses pembelajaran. Fitur dalam edmodo yang lengkap membuat siswa memahami materi dan mencari sehingga disini siswa memiliki skor tinggi. Dibuktikan dari hasil posttest siswa dapat menjawab sampai mendapatkan skor maksimal yaitu 100 dan skor minimal 80 .

Hasil penelitian ini mendapatkan hasil yang sesuai dengan penelitian terdahulu dimana media pembelajaran edmodo efektif digunakan dalam proses pembelajaran untuk meningkatkan kemampuan berpikir kritis siswa SD. Keterbatasan penelitian ini yaitu terbatas pada pembelajaran tematik kelas VI SD.

\section{KESIMPULAN}

Hasil penelitian tersebut menunjukkan kelas eksprimen lebih tinggi perolehan skor terhadap soal kemampuan berpikir kritis pada pembelajaran tematik. Berdasarkan hasil uji t-test media pembelajaran 
edmodo lebih efektif terhadap kemampuan berpikir kritis pada pembelajaran tematik kelas VI SD. Berdasarkan penelitian tersebut maka diharapkan guru dalam lingkup pendidikan selalu mengikuti perkembangan teknologi salah satunya memanfaatkan media pembelajaran berbasis digital untuk menunjang kegiatan pembelajaran yang dilaksanakan.

\section{DAFTAR PUSTAKA}

Aisyah, S., \& Kurniawan, M. A. (2021). Penggunaan Media Pembelajaran Daring Pada Masa Pandemi Covid19. Jurnal Riset Madrasah Ibtidaiyah ..., $\quad 1(1), \quad 48-56$. Http://Journal.Unugiri.Ac.Id/Index.Php/Jurmia/Article/View/195

Arsyad, A. (2019). Media Pembelajaran. Depok: Rajagrafindo Persada.

Diyanah, I., Atok, A. R. Al, \& Artikel, R. (2021). Peningkatan Kemampuan Berpikir Kritis Siswa Melalui Model Pembelajaran Kooperatif Tipe Jigsaw Dengan Media Game Monopoli The Improvement Of Student' S Critical Thinking Ability Through Jigsaw Type Cooperative Learning Model With Monopoly Game Media. 6, 201-209. Http://Journal2.Um.Ac.Id/Index.Php/Jppk/Article/View/16630/8235

Fitria. (2020). Pembelajaran E-Learning Berbasis Edmodo : Studi Kasus Di Sd Negeri 106 Pekanbaru. 1(1), 27-32. Https://Ejournal.Anotero.Org/Index.Php/Bedelau/Article/View/5

Gatot, Priowijanto. (2013). Materi Simulasi Digital. Jakarta: Seamolec.

Hobsbawm, E. (2007). Students ' Perceptions On The Effectiveness Of The Use Of Edmodo As A Supplementary Tool For Learning. Dlsu Research Congress, 6-11. Https://D1wqtxts1xzle7.Cloudfront.Net/45658692/Lli-Ii-010-Ft-With-Cover-Page-

V2.Pdf?Expires $=1639917454 \&$ Signature $=$ Xdd43mjwdfasfugwn3ewlbkoadmuesdowsosrm1x0zexwb6kb ji7pxwcdxcbjmhmnencqido-Ccolrd5z7kmat8orwtju8jexkxd-

Lwhg5mhqrsynvrngp08cjbxb5hyr1u4cyv0j Xmy-V-Eumrsxqhenyifyg77q129na Aetpctycxanutx2gaVidppdjvea4r-0rwarwxdczhfarajs0wzif-

Mshos7yy2xg2hxy Eyaf Rwnqrr D0lzuftbsdwihfpvyjqbi7fgadykm7qlqhpkzcmt30gdbj30cnlvkfoskkps zx6hmo87tvnpozowg9ipd9hhsuvnkw4q_\&Key-Pair-Id=Apkajlohf5ggslrbv4za

Inel Ekici, D. (2013). The Use Of Edmodo In Creating An Online Learning Community Of Practice For Learning To Teach Science. Malaysian Online Journal Of Educational Sciences, 5(2), 91-106.

Kustandi, C. (2017). Efektivitas E-Learning Berbasis Edmondo Dan Schoology Terhadap Kemampuan Berfikir Kritis Mahasiwa Program Studi Teknologi Pendidikan Fip Unj Pada Mata Kuliah Profesi Pendidikan. Journal Of Physics A: Mathematical And Theoretical, 2(1), 1-9. Http://Ejournal.UikaBogor.Ac.Id/Index.Php/Educate/Article/View/1034/853

Masnur, I. (2021). Efektivitas E-Learning. 2(1), 163-169. Https://Ummaspul.E-Journal.Id/Mgr/Issue/View/42

Muklis, M. (2012). Pembelajaran Tematik Pembelajaran Tematik Mohamad Muklis Stain Samarinda. Fenomena, Iv(1), 63-76. Doi: Https://Doi.Org/10.21093/Fj.V4i1.279

Nur, M. (2021). Media Pembelajaran E-Learning Menggunakan Aplikasi. 13, 1-5. Https://Journal.Unpak.Ac.Id/Index.Php/Pedagogia/Article/View/2743

Purnawarman, P., Susilawati, \& Sundayana, W. (2016). The Use Of Edmodo In Teaching Writing In A Blended Learning Setting. Indonesian Journal Of Applied Linguistics, 5(2), 242-252. Https://Doi.Org/10.17509/Ijal.V5i2.1348

Sari, I. K. (2021). Blended Learning Sebagai Alternatif Model Pembelajaran Inovatif Di Masa Post-Pandemi Di Sekolah Dasar. Jurnal Basicedu, 5(4), 2156-2163. Https://Doi.Org/10.31004/Basicedu.V5i4.1137

Sedono, S. (2012). Kelas I Melalui Pembelajaran Tematik Detujui Oleh. 
530 Efektivitas Media Pembelajaran Edmodo Terhadap Kemampuan Berpikir Kritis pada Pembelajaran Tematik Siswa Sekolah Dasar - Vivi Rulviana

DOI: https://doi.org/10.31004/basicedu.v6i1.1867

Shams-Abadi, B. B., Ahmadi, S. D., \& Mehrdad, A. G. (2015). The Effect Of Edmodo On Efl Learners ' Writing Performance. 2(2), 88-97.

Siahaan, Y. L. O., \& Meilani, R. I. (2019). Sistem Kompensasi Dan Kepuasan Kerja Guru Tidak Tetap Di Sebuah Smk Swasta Di Indonesia. Jurnal Pendidikan Manajemen Perkantoran, 4(2), 141. Https://Doi.Org/10.17509/Jpm.V4i2.18008

Siregar, S. (2013). Metode Penelitian Kuantitatif. Jakarta: Pt Fajar Interpratama Mandiri.

Sugiyono. (2017). Metode Penelitian Kuantitatif, Kualitatif, Dan R\&D. Bandung : Alfabeta, Cv.

Suriadhi, G., \& Tastra, I. D. K. (2014). Pelajaran Ipa Kelas Viii Di Smp Negeri 2 Singaraja. Edutech, 2(1). Https://Ejournal.Undiksha.Ac.Id/Index.Php/Jeu/Article/View/3795/3041

Winoto, Y. C., \& Prasetyo, T. (2020). Efektivitas Model Problem Based Learning Dan Discovery Learning Terhadap Kemampuan Berpikir Kritis Siswa Sekolah Dasar. Jurnal Basicedu, 4(2), 228-238. Https://Doi.Org/10.31004/Basicedu.V4i2.348 